\title{
CORRESPONDENCE
}

\section{Fictional narrative and psychiatrists}

Oyebode's ambitious review of psychiatry in fictional narrative (Oyebode, 2004) was most welcome. We should not underestimate the importance of literary and other media representation in creating the milieu in which we work. He is correct to emphasise that 'whether psychiatrists read these fictional accounts or not, the accounts will undoubtedly influence how wider society perceives mental illness'. Reading fictional accounts can also reveal to us in the business of mental illness how we are considered by wider society. It's fun as well.

The article examines the 'otherness' of the experience of being mentally ill. In exploring the deviance of characters in fiction, the violence with which they are associated and their (physical) removal from society it emphasises how people with mental illnesses are viewed as being different. Oyebode opens by explaining how 'fictional narrative achieves its aims by making its characters stand out'. Mentally ill characters stand out by being on the outside. They are set aside or, to put it more emotively, rejected by the mainstream. To understand better this decentred experience we can ask what lies at the centre. Superficially, we could simply reply 'everything else', but in the restricted world of these characters the psychiatrist is very often a significant representative of the society from which they have been distanced. It may be taken as given that in such a situation the psychiatrist is a symbol of authority. This association is inevitably greater when a protagonist is being detained against their will, or is receiving treatment without giving their consent. This is the case in the novels cited for their accounts of institutional care and ECT, Sylvia Plath's The Bell Jar (1963) and Janet Frame's Faces in the Water (1961). But perhaps more interesting are the images, symbols and associations employed to illustrate and convey the authority of the psychiatrist. Such portrayals often go beyond a simple representation of the power invested in the practitioner by way of his or her occupation. I have found that descriptions of psychiatrists are often imbued with and complicated by reference to other forms of authority such as religion or gender (male) dominance. The former is exemplified by Plath's treatment of ECT in one of her short stories, Johnny Panic and the Bible of Dreams, where Johnny Panic's top priests (the doctors) 'anoint' her on the temples (referring to the graphite conductant), and then 'robed in sheets virginal as the snow ... the crown of wire is placed on my head, the wafer of forgetfulness on my tongue' (Plath, 1968).

In another of Frame's asylum novels Owls Do Cry (1957), she describes memorably an encounter with a doctor:

'He stands with his hand resting lightly, it seems lightly, upon his treasure; then Daphne knows he dare not move his hand away from the voluptuous body of the red and black-eyed machine which, in case of escape, is fastened, as a lover secures the object of his love with cords of habit, circumstance, convenience, time, with black charged cords, varicose, converging to a unity that is controlled by a switch and pressure of the doctor's own hand ... He looks at Daphne, as if she may have interrupted his pleasure, or as if he will communicate to her, then blot from her knowing, the delight he feels in his lovely machine' (Frame, 1957: p. 47).

Fictional narrative is not well suited to conveying comprehensive knowledge of mental illness or the psychiatric profession - it simply deals in the wrong kind of data for that. However, it does offer the opportunity to explore heuristically these issues in an interesting way which helps us reflect on our practice. Coverage of this topic can only stimulate this self-discovery and justifies its inclusion in popular journals. Perhaps we would be enriched by finding some small place for it in more formal postgraduate education?

Frame, J. (1957) Owls Do Cry. Christchurch: Pegasus. Frame, J. (1961) Faces in the Water. Christchurch: Pegasus. Oyebode, F. (2004) Fictional narrative and psychiatry. Advances in Psychiatric Treatment, 10, 140-145. Plath, S. (1963) The Bell Jar. New York: Heinemann. Plath, S. (1968) Johnny Panic and the Bible of Dreams. London: Pan.

Andy Bickle Senior House Officer, Department of Learning Disability, Highbury Hospital, Highbury Road, Bulwell, Nottingham NG6 9DR, UK. E-mail: andy_bickle@lycos.co.uk 


\title{
NEW from the College Seminars Series
}

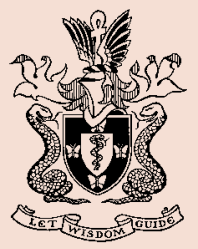

\section{Seminars in Clinical Psychopharmacology}

\author{
Second edition
}

Edited by David King

Psychopharmacology is the key both to rational prescribing in clinical psychiatry and to a fuller understanding of the biological basis of severe mental illness. The popularity of the first edition (from 1995) has led to this second edition, which has been updated, revised and extended to include a new chapter on the promising and rapidly growing area of pharmacogenomics. The bulk of it has been written by practising clinicians with an interest in the neuroscience base of psychiatry. The book is intended primarily for trainees in psychiatry and related disciplines, who are looking for a deeper understanding of recent scientific developments in psychopharmacology. It therefore aims to integrate theoretical pharmacology with clinical practice. The chapters are divided into three sections: (i) general principles, including receptor neuropharmacology, clinical pharmacokinetics and pharmacodynamics, (ii) the main psychotropic drugs used in general adult psychiatry, and (iii) special areas of psychotherapeutics.

September 2004, Paperback, 688pp, ISBN 190467108 X, Price $£ 30.00$

Order from: Book Sales, Royal College of Psychiatrists, 17 Belgrave Square, London SW1X 8PG. Tel: 02072352351 x146. Fax: 02072451231.

Website: www.rcpsych.ac.uk/publications

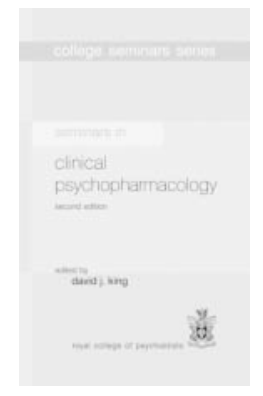

\section{Clinical Evidence Mental Health (third edition)}

Royal College of Psychiatrists/BMJ Publishing Group

This book contains the mental health section extracted from Clinical Evidence, Issue 11 (BMJ Publishing Group), the international source of the best available evidence for effective health care. The book presents clear, concise summaries of the current state of the evidence on the prevention and treatment of mental health disorders derived, where possible, from randomised controlled trials and systematic reviews.

This third edition covers 15 different mental health disorders, 27 questions, and over 200 interventions.

- Based on the latest Clinical Evidence search and appraisal results.

- Includes evidence on the short- and long-term treatment of mental health disorders and their complications.

- Assesses drug treatments, non-drug treatments and psychological therapies.

- Uses explicit methodology for selecting which evidence to summarise.

- Categorises interventions according to whether they have been found to be effective or not.

- Presents key messages and structured summaries of filtered evidence.

- Presents the balance between benefits and harms of intervention.

August 2004, Paperback, 210pp, ISBN 190467116 0, Price $£ 14.00$

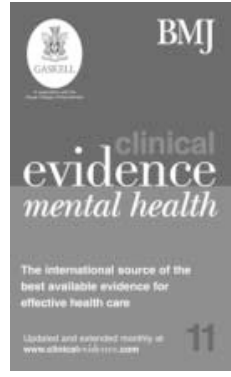

